DOI: 10.32844/2222-5374-2020-104-2.64

УДК: 347.6

Оганісян Ц. В.,

доцент кафедри цивільно-правових дисциплін

Дніпропетровського державного університету внутрішніх справ

\title{
ОКРЕМІ АСПЕКТИ ФІКТИВНОГО ШЛЮБУ: ПОНЯТТЯ, ПІДСТАВИ, НАСЛІДКИ
}

У науковій статті досліджується концепція, основи та наслідки фіктивного шлюбу за законодавством України, аналізується історична ретроспектива цього питання та досвід інших країн. У сучасних умовах, коли суспільство стикається з кризою сімейних цінностей, коли інститут шлюбу в останні роки знецінюється, держава повинна вжити дієвих заходів для подолання цих проблем. Шлюб може бути визнаний недійсним за рішенням суду, якщо він є фіктивним. Після укладення фіктивного шлюбу сторони здійснюють юридичні дії без наміру настання правових наслідків, передбачених законом. Підкреслюється, що саме відсутність наміру створити сім'ю є ознакою фіктивного шлюбу, і мотиви його укладення не мають юридичного значення. Зазначається, що фіктивний шлюб не є підставою для прав та обов'язків подружжя між особами, між якими він був зареєстрований. Якщо під час фіктивного шлюбу особи придбали майно, то воно вважається належним їм не на основі спільної власності, а на праві спільної власності відповідно до норм цивільного законодавства, а не сімейного права. При цьому розмір часток кожного з них визначається відповідно до їх участі у придбанні цього майна. Крім того, якщо особа при укладанні такого шлюбу змінила своє прізвище, вважатиметься, що воно називається цим прізвищем без достатньої правової підстави. Крім того, передшлюбний договір, укладений між такими особами, визнається недійсним. У той же час, якщо фіктивна сімейно-правова ситуація в майбутньому породжує не уявні, а справжні правовідносини, закон не надає фіктивного юридичного значення. Підкреслюється, що фіктивний шлюб у деяких краӥнах є основою притягнення особи до кримінальної відповідальності. Зазначається, що законодавство інших країн передбачає більш конкретні засоби доказування, які можуть бути використані у таких випадках. Зроблено висновок, що фіктивний шлюб слід розглядати не лише як фіктивну операцію, а як форму шахрайства. У цьому випадку для боротьби з фіктивними шлюбами слід посилити відповідальність, особливо у випадках фіктивних шлюбів з метою нелегальної міграції. Ймовірно, у законодавстві України може бути передбачений широкий спектр повноважень, що дасть змогу довести фіктивний характер шлюбу у випадках, коли позов про визнання шлюбу недійсним подає одна з осіб, права яких порушено у зв'язку з реєстрацією такого шлюбу.

Ключові слова: шлюб, фіктивний шлюб, недійсний шлюб, юридична відповідальність. 
Актуальність теми. На різних етапах розвитку суспільства шлюбні відносини трансформувалися в залежності від режиму правління та багатьох інших факторів. Але основна функція шлюбу у всі часи залишається незмінною. В сучасних умовах коли суспільство зіштовхнулося з кризою сімейних цінностей, коли впродовж останніх років знецінюється інститут шлюбу, держава повинна вжити дієвих заходів для подолання цих проблем. Відповідно Сімейного кодексу України шлюб - це сімейний союз жінки та чоловіка, зареєстрований у державному органі реєстрації актів цивільного стану. Однією з основних ознак шлюбу $є$ те, що це саме сімейний союз, що припускає спільне проживання і не тільки в фізичному сенсі, а й моральному, тобто спільний побут, взаємні права та обов'язки. Шлюб може визнаватися недійсним за рішенням суду у разі його фіктивності. При укладанні фіктивного шлюбу сторони вчиняють юридичні дії без наміру настання тих правових наслідків, які передбачені законом.

Аналіз останніх досліджень і публікацій. У науковій літературі проблематиці недійсних шлюбів приділяли увагу багато зарубіжних та вітчизняних вчених, зокрема: Ромовська 3.В., Бірюков I.А., Гопанчук В.С., Маслов В.Ф., Заїка Ю.О., Борисова В.І., Жилінкова І.В., Глиняна К.М., Войтенко Т.В., Пчелінцева Л.М., Ревуцька І.Е., Червоний Ю.С., Апопій І.В. та інші.

Метою даного дослідження $\epsilon$ проаналізувати поняття та особливості фіктивного шлюбу за законодавством України, дослідивши також історичну ретроспективу даної проблематики та досвід інших країн.

Виклад основного матеріалу. Ч. 2 ст. 40 Сімейного кодексу України встановлює, що фіктивним визнається шлюб, укладений без наміру створення сім'ї. Отже, саме відсутність наміру творення сім'ї $є$ ознакою фіктивного шлюбу, а мотиви його укладення не мають жодного юридичного значення. І. Ревуцька влучно стверджує, що фіктивний шлюб є прикладом деструктивної фікції в сімейному праві, виникнення якої значною мірою пов'язано з негативними соціально-економічними явищами, подолання яких іншим чином ставало неможливим [10, с. 101]. На думку М. Антокольської, правова природа фіктивного шлюбу подібна до правової природи уявного правочину, адже в обох випадках юридичні дії вчиняються без наміру створити наслідки, передбачені для них законом [1, с. 124].

Поява поняття «фіктивний шлюб» у судовій практиці відноситься до 1949 року, але його законодавче закріплення відбулося лише через майже 20 років, у 1968 році. За радянських часів укладення фіктивних шлюбів було пов'язане здебільшого з наявністю значної кількості нормативних заборон, зокрема стосовно свободи вибору місця проживання. Так, досить поширеним було укладання фіктивного шлюбу з метою отримання прописки, права на житлову площу, ухилення роботи за призначенням після закінчення вищого навчального закладу, отримання можливості еміграції.

Сьогодні фіктивні шлюби найчастіше укладаються з метою отримання громадянства або як спосіб приховання нетрадиційної орієнтації. Так, досить значна кількість осіб сподівається знайти краще життя в іншій країні саме через укладення шлюбу з іноземцем [9, с. 107].

Необхідно зазначити, що фіктивні шлюби можуть укладатися також і з інших причин. В науковій літературі набув розголосу наступний випадок: А. С. та М. С. працювали лікарями обласної клінічної лікарні. На 
лікуванні у ній перебував П., самотній удівець, інвалід війни, з онкологічним захворюванням четвертого ступеня, який проживав у приватизованій квартирі у престижному районі міста. Подружжя, оскільки у них діти були вже повнолітні, негайно подали до органу РАЦСу заяву про розірвання шлюбу, і через місяць у лікарні було зареєстровано шлюб між М. С. та П. Після цього його було виписано з лікарні додому. М. С. доглядала П., який через три дні помер. Після розголосу пресою цієї події прокурором було пред'явлено позов про визнання шлюбу недійсним через його фіктивність. Суд задовольнив позов, мотивуючи своє рішення тим, що до розлучення А. С. та М. С. мали належні подружні стосунки (проживали однією сім'єю, вели спільне господарство, виконували інші, подібні за змістом права та обов'язки подружжя). Очевидним виявився той юридичний факт, що раніше, до моменту стаціонарного лікування в клінічній лікарні, М. С. та П. не були знайомі одне з одним. Зазначені фактичні обставини справи дали законні та обгрунтовані підстави вважати, що М. С. на момент посвідчення шлюбу мала оманливий намір - спадкування нерухомого майна після смерті чоловіка. Додатково позивач ставив під сумнів питання дієздатності особи померлого на момент реєстрації шлюбу: чи здатний був П. розуміти юридичне значення своїх дій [6, с. 33].

Т.В. Войтенко зазначає, що найчастіше підставами для визнання шлюбу недійсним у зв'язку з відсутністю у сторін чи сторони наміру створювати сім'ю та набувати прав та обов'язків подружжя, вказують наступні: окреме проживання, відсутність спільно набутого майна, відсутність турботи один про одного та взаємної матеріальної підтримки, не показування подружніх відносин перед третіми особами, відкрите демонстрування перед третіми особами відсутності фактичних шлюбних відносин та наголошення фіктивності реєстрації шлюбу [4]. Водночас велика вікова різниця або матеріальний розрахунок, задля досягнення якого особа одружується, чи небажання мати дітей не можуть трактуватися як достатній доказ відсутності наміру створити сім'ю [11, с. 101-102].

Слід підкреслити, що саме по собі укладання шлюбу з корисливою метою не є підставою для визнання його недійсним, адже лише відсутність наміру створити сім'ю $є$ визначальним фактором. I.В. Атопій слушно наголошує, що основною відмінністю фіктивних шлюбів від шлюбів з розрахунку $є$ те, що в другому випадку особа бажає створити сім'ю, оскільки матиме вигоду саме під час перебування у шлюбі, чого не можна сказати про фіктивні шлюби [2; с. 78]. Саме тому, здійснюючи оцінку шлюбу на предмет його можливої фіктивності, суд бере до уваги усю сукупність обставин справи: тривалість шлюбу, спільне чи роздільне проживання, наявність чи відсутність спільного господарства, участь кожного з подружжя у його веденні, наявність чи відсутність спільних дітей, причини відсутності дітей, спілкування дружини, чоловіка з пасинком, падчеркою та ін. [12, с. 108].

У постанові Касаційного цивільного суду ВС від 17.04.2019 у справі № 752/2337/16-ц суд зазначив, що причини реєстрації фіктивного шлюбу можуть бути різними, як правило вони пояснюються та обумовлюються бажанням отримати певні права, підставою виникнення яких самостійно чи у складі інших юридичних фактів $є$ шлюб, наприклад, отримання спадщини, житлової площі тощо. У випадку встановлення фіктивності шлюбу намір 
визначається стосовно речей неправового характеру - бажання проживати разом, вести спільне господарство, дбати про добробут та моральний стан сім “̈ тощо. Саме по речах неправового характеру, що супроводжують відносини осіб після реєстрації шлюбу, можна визначити намір осіб щодо шлюбу.

У справі № 285/720/16-ц Верховний Суд дійшов висновку, що окреме проживання подружжя та непроведення святкової церемонії укладання шлюбу, а також наявність будь-яких фінансових зобов'язань сторін самі по собі не можуть бути підставою для визнання шлюбу недійсним (фіктивним). А припинення сімейних стосунків та наявні конфлікти, які виникають між подружжям, є підставою для розірвання шлюбу, а не для визнання його недійсним.

Водночас доведення фіктивності шлюбу, особливо у випадках, коли мав місце умисел обох сторін, все одно залишається досить важкою процедурою. Згідно з чинним законодавством подружжя не зобов'язане проживати разом, тому їх роздільне місце проживання ще не свідчить про відсутність наміру створити сім'ю і не може автоматично розглядатися як доказ фіктивності шлюбу.

Роздільність проживання подружжя може обумовлюватися обставинами тимчасового характеру (наприклад, служба в армії, навчання іншому місті, догляд за непрацездатними родичами тощо) і за відсутності інших поважних обставин сама по собі не може бути підставою для визнання шлюбу недійсним.

За чинним законодавством України фіктивний шлюб не є підставою для виникнення у осіб, між якими він був зареєстрований, прав та обов'язків подружжя. Якщо протягом фіктивного шлюбу особи набули майно, то воно вважається таким, що належить їм не на праві спільної сумісної власності, а на праві спільної часткової власності відповідно до положень не сімейного, а цивільного законодавства. В цьому випадку, розмір часток кожного з них визначається відповідно до їхньої участі у придбанні цього майна. Також, якщо особа при укладенні такого шлюбу змінила своє прізвище, то вона вважається такою, що іменується цим прізвищем без достатньої правової підстави. Крім того, укладений між такими особами шлюбний договір визнається недійсним [7, с. 23].

Водночас, якщо фіктивний сімейно-правовий стан у подальшому породжує не уявне, а дійсне правовідношення, закон не надає фіктивності юридичного значення [10, с. $102 ; 8$, с. 22-23]. Зокрема, відповідно до ч. 3 ст. 40 СК України шлюб не може бути визнаний недійсним, якщо на момент розгляду справи судом відпали обставини, які засвідчували небажання особи створити сім'ю. 3 цього приводу Верховний Суд зазначив, що відсутність наміру створити сім ю у момент укладення шлюбу може бути цілком компенсовано його появою після реєстрації шлюбу, коли за всіма об`єктивними обставинами можна стверджувати, що у особи з`явився намір створити сім ю, наприклад коли після реєстрації шлюбу, який мав ознаки фіктивності, особи почали разом проживати, вести спільне господарство, дружина завагітніла або у подружжя народилися діти, батько піклується про дружину та дітей, подружжя запрошує до себе своїх батьків та друзів, підтримують інтимні стосунки, разом відпочивають та відвідують своїх рідних та близьких тощо (постанова від 17.04.2019 у справі № 752/2337/16-ц). 
Як негативне явище, фіктивний шлюб у деяких країнах $є$ підставою для притягнення особи для кримінально-правової відповідальності. Так, О. Верейці зазначає, що у Німеччині за укладення фіктивного шлюбу з метою отримання виду на проживання та соціальних пільг передбачена кримінальна відповідальність до трьох років ув'язнення та значний штраф [3, с. 179-180]. Кримінальну відповідальність за укладання фіктивного шлюбу з метою отримання бельгійського громадянства у вигляді ув'язнення на строк до двох років передбачає також законодавство Бельгії [5].

За законодавством США вступ у шлюб без наміру створити сім'ю, а лише з метою підвищити свій рівень життя, отримати певні юридичні переваги або приховати вагітність, або пожартувати над будь-ким $є$ підставою для визнання шлюбу недійсним [4].

У Швейцарії подружні пари, які викликають підозру, зокрема, де один з подружжя - іноземець, щороку підлягають поліцейським перевіркам з метою встановлення факту спільного проживання подружжя, ведення спільного господартства тощо.

В 2007 р. в Чехії було прийнято зміни до законодавства і криміналізовано дії щодо допомоги іноземцям в незаконному перебуванні на території Чеської Республіки. Таким чином, поліція та суди припинили поблажливо ставитись до фіктивних шлюбів з іноземцями, оскільки за укладення фіктивного шлюбу особа може бути притягнена до кримінальної відповідальності [14].

Законодавством Португалії передбачено покарання обох сторін при укладанні фіктивного шлюбу з метою легалізації в країні. Покаранням $\epsilon$ позбавлення волі від року до чотирьох років, а організатори шлюбних шахрайств підлягають тюремному ув'язненню строком до п'яти років.

Слід зазначити, що у законодавстві інших країн передбачено більш конкретні засоби доказування, які можуть бути застосовані у подібних справах. Так, у Німеччині поліція має право ходити до подружжя й перевіряти, чи є особисті речі, сімейні фотографії, запитувати про смаки, звички чоловіка, спілкуватись з сусідами тощо.

Висновки. Таким чином, фіктивний шлюб, на нашу думку, необхідно розглядати не лише як фіктивний правочин, а як різновид шахрайства. В цьому випадку з метою боротьби з фіктивними шлюбами слід посилити відповідальність, особливо це стосується випадків укладення фікивних шлюбів з метою нелегальної міграції. Ймовірно, ширше коло повноважень можна передбачити і в законодавстві України, щоб зробити можливим доказування фіктивності шлюбу у випадках, коли позов про визнання шлюбу недійсним пред'явлений однією із осіб, вказаних у ст.42 Сімейного кодексу України - особи, права яких порушені у зв'язку з реєстрацією такого шлюбу, батьки, опікун, піклувальник дитини, опікун недієздатної особи, прокурор, орган опіки та піклування.

\section{СПИСОК ВИКОРИСТАНИХ ДЖЕРЕЛ}

1. Антокольская М. В. Семейное право : учебник. М :Юристъ, 2002. $336 \mathrm{c}$. 
2. Атопій І.В. Проблеми визнання шлюбу недійсним в судовому порядку. Актуальні проблеми удосконалення чинного законодавства України. 2008. Вип.20. С.74-83.

3. Верейці О. Застосування презумпцій та фікцій у регулюванні сімейних відносин. Мала енциклопедія нотаріуса. 2016. Жовтень. № 5 (89). С. $174-181$.

4. Войтенко Т.В. Фіктивність шлюбу як підстава його недійсності. Мaтер. науково-практичної інтернет-конференції «Актуальна юриспруденція» URL: http//legalactivity.com.ua

5. Коголовский И.Р. Фиктивные состояния в семейном праве URL: http://www.to-1.ru/articles/425/

6. Кожевнікова В. Обмеження права чоловіка та жінки на укладення шлюбу без наміру створити сім'ю. Підприємнищтво, господарство і право. 2017. № 8. С. 32-34

7. Лукаш Я.Л., Лях І.В. Фіктивний шлюб і шлюб із розрахунку: порівняльно-правові аспекти. Тенденции, наработки, инновации, практика в науке. г. Люблин. 2014. С.23-24.

8. Маркосян А.В. Юридические факты в семейном праве Российской Федерации : автореф. дисс. на соискание уч. степени канд. юрид. наук : спец. 12.00.03. М., 2007. 24 с.

9. Ревуцька I.Е. Особливості укладення шлюбу з іноземним елементом. Римське право і сучасність (Шерешевські читання): матеріали Міжнародної наукової конференції, 11 травня 2012 р., Одеса. Ч.1. За заг. ред.: Є.О. Харитонов; Нац. ун-т «Одес. юрид. акад.», Нац. акад. прав. наук України, Півд. регіон. центр, Ужгород. нац. ун-т. Ужгород: Говерла. 2012. С.107 - 109.

10. Ревуцька І.Е. Правові підстави створення сім'ї за законодавством України та країн-членів ЄС: порівняльно-правова характеристика : дис.... канд. юрид. наук: 12.00.03. Івано-Франківськ. 2018. 207 с.

11. Ромовська 3.В. Сімейний кодекс України: Науково-практичний коментар. К.: Видавничий Дім «Ін Юре». 2003. 532 с.

12. Сімейне право України: підручник. За заг. ред. Т.В. Боднар та О.В. Дзери. К.: Юрінком Інтер, 2016. 520 с.

13. Сімейний кодекс України: Закон України від 10. 01.202 № 2497-III URL: http//zakon1.rada.gov.ua.

14. Фіктивні шлюби чехів у Донецьку URL: http://ukrzurnal.eu/ukr. archive.html/164/

\section{Ts. Ohanisian}

\section{CERTAIN ASPECTS OF FICTITIOUS MARRIAGE: CONCEPTS, GROUNDS, CONSEQUENCES}

The scientific article explores the concept, foundations and consequences of fictitious marriage under the laws of Ukraine, analyzes the historical retrospective of this issue and the experience of other countries. In modern conditions, when society is faced with a crisis of family values, when the institution of marriage has been depreciating in recent years, the state must take effective measures to overcome these problems. A marriage may be invalidated by a court decision if 
it is fictitious. At the conclusion of a fictitious marriage, the parties commit legal actions without the intention of occurring the legal consequences provided for by law. It is emphasized that it is precisely the lack of intention to create a family that is a sign of a fictitious marriage, and the motives for concluding it have no legal significance. It is noted that a fictitious marriage is not a basis for the rights and obligations of spouses between the persons between whom it was registered. If during a fictitious marriage, persons acquired property, then it is considered to belong to them not on the basis of common joint ownership, but on the right of common shared ownership in accordance with the rules of civil law rather than family law. In this case, the size of the shares of each of them is determined in accordance with their participation in the acquisition of this property. Also, if a person at the conclusion of such a marriage has changed his surname, it shall be considered that he is called by that surname without a sufficient legal basis. In addition, a prenuptial agreement concluded between such persons shall be recognized as invalid. At the same time, if a fictitious family legal situation in the future generates not an imaginary, but a true legal relationship, the law does not provide fictitious legal significance. It is emphasized that fictitious marriage in some countries is the basis for bringing a person to criminal liability. It is noted that the legislation of other countries provides more specific means of proof that can be used in such cases. It is concluded that a fictitious marriage should be considered not only as a fictitious transaction, but as a form of fraud. In this case, in order to combat fictitious marriages, responsibility should be strengthened, especially in cases of fictitious marriages for the purpose of illegal migration. Probably, a wide range of powers can be assumed in the legislation of Ukraine in order to make it possible to prove the fictitious nature of the marriage in cases when the claim for declaring the marriage invalid is brought by one of the persons whose rights have been violated in connection with the registration of such marriage.

Keywords: marriage, fictitious marriage, void marriage, legal liability. 